\title{
Evaluating combined project management models: strategies for agile and plan-driven integration
}

\author{
Felipe Barreto Silva, Michael Jordan Bianchi, Daniel Capado Amaral \\ Escola de Engenharia de São Carlos, Universidade de São Paulo - USP \\ e-mails: felipebarretosilva@gmail.com; michael_bianchi@usp.br; amaral@sc.usp.br
}

\begin{abstract}
The combination of agile and traditional practices is important for greater innovation in New Product Development (NPD). This paper analyzes ten combination proposals found in the literature, using the systematic bibliographical review method. Four of them did not show features associated with the combination. Four proposals recommend using agile project management associated with NPD process. Two proposals recommend using a general project plan, prepared through Work Breakdown Structure, scheduling, and integrated with agile iteration planning. The evaluation of these proposals indicated a shortage of recommendations and revealed two classes of combination strategies, namely bottom up and top down.
\end{abstract}

Keywords: agile, traditional, plan-driven, hybrid, combination, balance.

\section{Introduction}

Agile Project Management (APM) practices have been applied in an increasing number of companies. Some of the practices used most often by project management professionals include: rapid response to strategic opportunities $(75 \%)$; short production cycle and decision making (64\%); and engaging the customer and integrating the customer's voice (54\%) (PROJECT..., 2012).

APM practices are important when managing complex and uncertain projects (FERNANDEZ; FERNANDEZ, 2008). However, in the context of large or complex projects that include hardware, there are barriers to the effectiveness of these practices, for example, the size of the team and the difficulties of prototyping, rapid changes in the projects and incorporating new features in the final stages of development. There are also challenges in managing interdependencies that require extensive coordination among project teams (BARLOW et al., 2011).

One alternative to overcoming these barriers is to combine the principles, practices, or tools of agile and traditional approaches. For example, Boehm and Turner (2005) studied the implementation of APM in environments that predominantly employed the traditional approach and identified the companies combining them in a single project. Another example is a global survey on agility in project management, with a sample of 856 professionals, which identified approximately 60 professionals combining the two approaches for managing projects (CONFORTO; REBENTISCH; AMARAL, 2014).
Batra et al. (2010) state that large, strategic, distributed project environments involving outsourcing require practices associated to traditional methods such as coordination, control, and communication. Furthermore, evolving requirements, organizational, technological, and unforeseen changes, and discovery of new features require agile methods for allowing adaptation to the changes. These environmental characteristics pose challenges that no single approach can effectively deal with; it would be necessary to combine them.

Since the beginning of the agile management movement, it has been possible to locate conceptual models, frameworks, and procedures in order to demonstrate how to perform this combination of approaches. One such example was Boehm and Turner (2003). Since then, other theorists have emerged with proposals for models.

To what extent are these models actually a combination of practices? What are the problems or maturity levels of these models? This paper analyzes the combination proposals found in the literature, using the systematic bibliographical review method. Ten combination proposals were identified, among models, methods, and frameworks.

\section{Research method}

The research method used in this study comprised a Systematic Literature Review (SLR), which was used as a tool to identify combination proposals, and a qualitative 
analysis to identify project management practices employed in the proposals.

The SLR followed the five steps established by Conforto, Amaral and Silva (2011): (1) the research problem; (2) primary sources of information on the phenomenon under study; (3) search keywords; (4) criteria for inclusion in the review; and (5) reading the articles.

The research problem is: "How can agile and traditional project management practices be combined?" The research is interested in identifying proposals for combining project management approaches in the literature, including models, methods, frameworks, and tools, among others.

The primary sources comprised the most cited papers on the subject identified in the initial review. Boehm (2002) and Boehm and Turner $(2003,2005)$ are works that introduced the debate on combining, while Vinekar, Slinkman and Nerur (2006) discuss ambidexterity for project management.

The databases are set based on Magdaleno, Werner and Araujo (2012). The authors conducted a quasi-systematic research to investigate the combination of software development models, Agile, Traditional, and free open source development. Their best research results are on three main databases: ISI Web of Knowledge, IEEE Xplore, and Compendex. Thus, this research adopted these three databases to find the proposals.

The keywords were identified from the initial review. The articles invariably quoted one of the agile methods, such as Scrum or Extreme Programming, as well as a term opposing the agile methods, such as traditional, PMBoK, or Plan-driven. Therefore, an article of interest to the study needs to cite both terms, for example, Scrum and Plan-driven. Other keywords were identified in Magdaleno, Werner and Araujo (2012), which referred to traditional management (e.g. CMMI, waterfall, and discipline) and were included in the study. Table 1 shows the search strings formed from the keywords.

The result returned 317 articles when applying the strings in the Web of Science ${ }^{\circledR}$ database. Upon a first reading of the titles and abstracts, it was apparent that the result included works from areas outside project management, for example, agile manufacturing, supply chain, healthcare, and materials (laser and microwave). It was necessary to create string number 4 to filter these articles. The new result returned 274 articles.

Inclusion criteria (IC) for articles in the study were formulated from the research problem and correspond to:

- IC1 - The article must discuss a combination of agile and traditional approaches;

- IC2 - The article must present a model, method, or framework, or propose a combination.

The titles and abstracts of the 274 articles were first perused to identify the debate on combining approaches. Consequently, 55 articles satisfied the first inclusion criterion, and 32 of them were selected after reading the introduction and conclusion. The full reading of the 32 articles considered the second inclusion criterion and the result indicated eight articles that presented combination proposals.

The search used the command search to set up the string in the IEEE Xplorer ${ }^{\circledR}$ database, which is presented in Table 2. The first result returned 1,314 articles published in Journals and Magazines. When analyzing the string, we discovered the term "discipline" used in Web of Science ${ }^{\circledR}$ is not a good qualifier. Thus, the term was removed from the string. The new result returned 170 articles when removing the term from research string. Among those articles, one

Table 1. Search strings used in ISI Web of Science.

\begin{tabular}{|c|l|l|}
\hline ID & \multicolumn{1}{|c|}{ String } & \multicolumn{1}{|c|}{ Justification } \\
\hline 1 & $\begin{array}{l}\text { (Agile or “Agile project management" or Scrum or "Extreme } \\
\text { Programming") }\end{array}$ & Identify articles that deal with agile project management \\
\hline 2 & $\begin{array}{l}\text { AND (Traditional or "plan-driven" or waterfall or discipline or } \\
\text { CMM or CMMI or PMBOK) }\end{array}$ & Identify the name of the term opposing agile \\
\hline 3 & $\begin{array}{l}\text { AND (Model or procedure or framework or method or approach } \\
\text { or methodology or process or practice or technique) }\end{array}$ & Identify combination proposals \\
\hline 4 & NOT ("agile manufacturing" or "Supply Chain" or "healthcare") & $\begin{array}{l}\text { Remove articles on agile manufacturing, supply chain, and } \\
\text { healthcare }\end{array}$ \\
\hline
\end{tabular}

Table 2. Search string used in IEEE Xplorer and Compendex.

\begin{tabular}{|c|c|}
\hline Datase & String \\
\hline IEEE Xplore & $\begin{array}{l}\text { (“Abstract”: “Agile approach" OR “Agile project management” OR Scrum OR "Extreme Programming” AND "Abstract”: } \\
\text { "Traditional Approach" OR "plan-driven” OR warterfall OR CMM OR CMMI OR PMBoK) }\end{array}$ \\
\hline Compendex & $\begin{array}{l}\text { ((((Agile or “Agile approach" or "Agile project management” or Scrum or "Extreme Programming”)) WN KY) AND } \\
\text { ((("Traditional Approach" or "plan-driven” or warterfall or CMM or CMMI or PMBoK))WN KY)) AND (English WN LA) }\end{array}$ \\
\hline
\end{tabular}


combination proposal was founded. The search did not include Congress Proceedings.

The result indicated 68 articles published in the Compendex ${ }^{\circledR}$ database when refining the search by English publications. This search not found any new model.

The search also considered books of traditional and agile project management, where another model was identified. Therefore, the final result of the research reached ten proposals for combining project management approaches.

The qualitative analysis of the combination proposals utilized the study by Eder et al. (2014). The authors investigated the main differences between the traditional and agile approaches and the result presented six primary differentiating characteristics. These six characteristics are assigned as criteria to analyze the combination proposals and to distinguish which practices were being combined.

The subsequent sections of the study are divided in the following order. Section three describes the ten proposals for combining project management approaches. Section four presents the analysis of the proposals and the classification of the characteristics of Eder et al. (2014). Section five presents the discussion and the study's conclusions.

\section{Theorectical background: agile and traditional project management practices}

Differentiate Traditional Project Management (TPM) from Agile Project Management (APM) is not a simple task. One way to differentiate them is classifying the project environment identifying elements like planning rules, controlling style, work execution, and user involvement (BOEHM; TURNER, 2005; SHENHAR; DVIR, 2007; SERRADOR; PINTO, 2015). Another way is identifying TPM and APM practices used by companies to manage their projects. The objective to differentiate the project management approaches is compare performance, advantages, and disadvantages in adopt them in a specific environment (EDER et al., 2014).

The problem arises when it is necessary classify the project management practices. TPM practices are commonly associated to standardized practices in guides such as PMBoK, ISO, IPMA, and Waterfall model (BOEHM; TURNER, 2005; BINDER; AILLAUD; SCHILLI, 2014; EDER et al., 2014; WYSOCKI, 2007), for example, Work Breakdown Structure and Project Schedule. APM practices are associated to Scrum, Extreme Programming (XP), and other agile methods. However, APM practices are not as well standardized as TPM. Comparing Scrum and XP, common practices have different names, for example the Sprint Planning and Iteration Planning respectively.

The classification of project management practices motived Eder et al. (2014) to conduct their research. They defined a project management practice as an activity composed of three keys elements: actions (which produce results), techniques (systematic procedure) and tools (artifacts which support the action). Figure 1 presents the three elements of the project management practice.

Eder et al. (2014) used this definition of project management practice to identify practices from APM and TPM through a Systematic Literature Review (SLR). The review used databases like Web of Science ${ }^{\circledR}$ and Scopus ${ }^{\circledR}$ to research for articles and included project management books. The SLR resulted in a list of 23 actions, 54 techniques and 21 tools, which is presented in Appendix 1.

The list of practices is used to observe four project management teams of two distinct organizations. The organizations are selected based on five criteria: (1) Organization must have a project management process; (2) The project team must identify itself as user of TPM or APM; (3) Develop innovative projects; (4) Develop products or technology (hardware, software, or both); (5) Must be a medium or large organizations.

The interview was conducted with members and leaders of these four project management. They presented documents and forms that illustrated the project management process and classified the practices used by their project team using Eder et al. (2014) list.

The conclusion of their work are six main characteristics those distinguish APM from TPM. One characteristic corresponds to a set of specific planning, controlling, or execution actions. The Table 3 resumes the list of characteristics for identifying an organization's project management approach.

In the context of this research, a combined proposal or hybrid approach need be assessed to identify the project management practices adopted by the author because is important discuss specifics recommendation for researchers develop hybrid methods and models and measure their performance in practice. Therefore, this paper assumes Eder et al. (2014) six characteristics to support the research in assess the project management practices even though their study only two organizations and their result need be conformed using surveys or a larger number of cases.

The six characteristics are used to assess ten combining proposal find in the literature. First, this paper discusses ten proposals for combining project management approaches and classifies the project management practices.

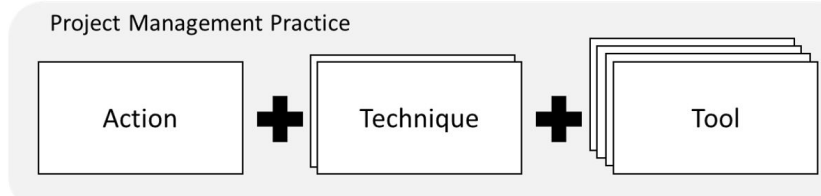

Figure 1. Project management practice elements. Source: Eder et al. (2014). 
Table 3. Characteristics for identifying an organization's project management approach.

\begin{tabular}{|c|c|c|}
\hline CHARACTERISTICS & TRADITIONAL APPROACH & AGILE APPROACH \\
\hline $\begin{array}{l}\text { 1) Planning levels - The way in which the } \\
\text { project plan is developed }\end{array}$ & $\begin{array}{l}\text { Single project plan that covers the total project } \\
\text { time and includes the products, deliveries, work } \\
\text { packages, and activities. }\end{array}$ & $\begin{array}{l}\text { There are two project plans: a) general plan that } \\
\text { considers the project's total duration and only the } \\
\text { main products; b) short-term plan that contains } \\
\text { only the deliveries and activities related to a } \\
\text { fraction of the project time (iteration). }\end{array}$ \\
\hline $\begin{array}{l}\text { 2) Scope - The way in which the project } \\
\text { scope is described }\end{array}$ & $\begin{array}{l}\text { Accurate description of the final result in textual } \\
\text { form with rules of contract type, objective } \\
\text { numbers, and performance indicators. }\end{array}$ & $\begin{array}{l}\text { Description of the final result in a comprehensive, } \\
\text { challenging, ambiguous, and metaphorical way. }\end{array}$ \\
\hline $\begin{array}{l}\text { 3) Task definition - The level of detail and } \\
\text { standardization with which each project } \\
\text { activity is defined }\end{array}$ & $\begin{array}{l}\text { The activities are described in a standardized } \\
\text { way and organized in WBS lists. They contain } \\
\text { codes and are classified in sets of work packages, } \\
\text { deliveries, and project product. }\end{array}$ & $\begin{array}{l}\text { There is no standard for describing the activities } \\
\text { that can be written in the form of stories, } \\
\text { problems, actions, or deliveries. There is no } \\
\text { attempt at organization, only the prioritization of } \\
\text { what should be undertaken at the time. }\end{array}$ \\
\hline $\begin{array}{l}\text { 4) Timespan for ultimate task - The } \\
\text { planning horizon of the activities } \\
\text { pertaining to the project team }\end{array}$ & $\begin{array}{l}\text { The activity lists are valid for the project's total } \\
\text { horizon. }\end{array}$ & $\begin{array}{l}\text { The activity lists are valid for an iteration that } \\
\text { is defined as a fraction of the total project time. }\end{array}$ \\
\hline $\begin{array}{l}\text { 5) Control - The strategy used to control } \\
\text { the project time }\end{array}$ & $\begin{array}{l}\text { Reports with performance indicators, written } \\
\text { documents, audits, and phase transition analyses } \\
\text { are used. Team meetings are infrequent. }\end{array}$ & $\begin{array}{l}\text { Visual devices are used that indicate physical } \\
\text { delivery of the final result (posters, stickers, etc.). } \\
\text { Meetings are short and frequent. }\end{array}$ \\
\hline $\begin{array}{l}\text { 6) Quality Assurance - The strategy used } \\
\text { to guarantee the achievement of project } \\
\text { scope }\end{array}$ & $\begin{array}{l}\text { The project manager evaluates, prioritizes, } \\
\text { adds, or changes the project activities so that } \\
\text { the results conform to the project scope agreed } \\
\text { with the client. }\end{array}$ & $\begin{array}{l}\text { The client evaluates, prioritizes, adds, or changes } \\
\text { the project's final product, according to the } \\
\text { results. The team will modify the activities to } \\
\text { obtain the results proposed by the client. }\end{array}$ \\
\hline
\end{tabular}

Source: Eder et al. (2014), translated by the authors.

\section{Proposals for combining project management approaches}

\subsection{Risk approach}

The Risk Approach is a method for choosing between agile and traditional approaches, whose goal is to develop strategies to mitigate the risks that dominate the project (BOEHM; TURNER, 2003, 2004). Figure 2 summarizes the steps of the proposed approach.

The combination occurs in step 3 when it is not possible to identify whether traditional or agile risks dominate the project, thus requiring both the approaches to mitigate the risks. The proposal is to create an architecture that supports the use of both the approaches, identifying the interfaces and isolating dynamic parts to minimize risks. In cases where it is not possible to create the architecture, the use of traditional methods is recommended for execution and feedback, and to identify the agile risks and develop strategies to mitigate them.

However, The Risk Approach does not address specific recommendations or details about how combine agile and traditional practices. In this way, the method relevance is to characterize the risks associated with the project and indicate the combination. The Risk Approach is not a combination proposal, although some authors defend it (GALALEDEEN; RIAD; SEYAM, 2007; BARLOW et al., 2011).

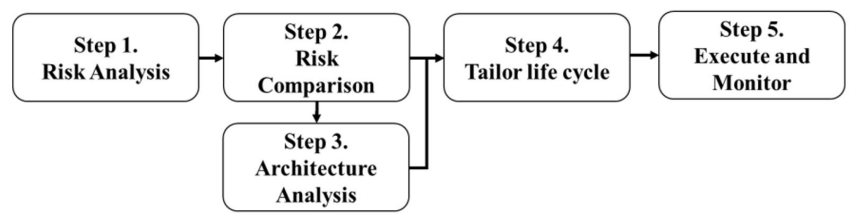

Figure 2. Summary of the Risk Approach (BOEHM; TURNER, 2004), simplified by the author.

\subsection{Xprince: extreme programming in controlled environments}

XPrince is a proposal for software development that aims to balance the agility of Extreme Programming (XP) and the discipline of traditional methods (NAWROCKI et al., 2006).

The proposal consists of a project life cycle based on XP, PRINCE2, and the Rational Unified Process (RUP). Figure 3 shows the five stages established in this proposal: Starting up a Project, Initiating a Project, Elaboration, Release, and Closing.

XPrince adopts elements of TPM and APM that indicate the combination. The authors recommend in the initiation phase of planning prepare the Business Case and create a comprehensive project plan, which represents all the releases and key product features. These recommendations are associated with TPM. The second point is iterative development and partial deliveries through releases, which is a characteristic practice of agile management. 
However, only three practices were found in XPrince, the action the project work identification associated to both project management approaches, the traditional technic develop the business case, and agile technic product architecture. The proposal does not provide enough information that permits the discussion about the practices need for a combination. The relevance is the recommendation to combine the process stages and iterative development.

\subsection{Hybrid process of design methodology}

The Hybrid Process of Design Methodology was developed from Adaptive Software Development (ASD) and New Product Development (NPD) (RAHIMIAN; RAMSIN, 2008). Figure 4 illustrates the process.

This proposal adopts only two agile practices, requirements prioritization action and product architecture technique. No traditional practices were identified. In addition, there are not specific details that assist the combination. The study essentially proposes the process of necessary stages for developing mobile phone software, recommending the integration of NPD activities such as idea generation in the early development stage, marketing tests at the end of the process, and establishing a life cycle for the software with agile iteration development.

\subsection{Hybrid framework}

The Hybrid framework is the result of a case study that investigated when and where it is necessary to combine approaches in the context of Distributed Agile Development (DAD) (BATRA et al., 2010). Figure 5 shows the framework.
The proposal indicates the traditional principles provides planning, control, and coordination activities, which are critical for distributed development, combined with agile principles as a response vehicle for the dynamics and uncertainties of the environment's requirements. For example, managing the user's requirements is difficult to deal with using agile methods and the authors discuss a case in which, by adopting the practice of controlling the project scope, the Steering committee achieved strategic benefits (BATRA et al., 2010)

However, The Hybrid framework adopts only agile practices, Control scope changes and requirements prioritization actions, product backlog and Daily Scrum Meeting techniques. There are not defined traditional practices that indicate the combination. In this way, the proposal does not differ from others agile methods. The authors should detail and improve the proposal to indicate the practices to be combined.

\subsection{Disciplined hybrid process model}

Zaki and Moawad (2010) devised a process model with six steps for software development, as illustrated in Figure 6.

The model adopts essentially agile practices. For example, in the initial stage, there is a recommendation to collect user stories and prepare the product backlog. The planning stage includes the estimation of all the collected stories, the prioritization of the user stories together with the clients and the establishment of the first Release date.

The traditional practices are recommended in order to address 16 agile issues. For example, agile principles assume the client is accessibility for making project

\begin{tabular}{|c|c|c|c|c|c|c|c|c|c|}
\hline \multirow[b]{2}{*}{$\begin{array}{c}\text { Starting } \\
\text { up a } \\
\text { Project }\end{array}$} & \multirow[b]{2}{*}{$\begin{array}{c}\text { Initianting } \\
\text { a project }\end{array}$} & \multirow[b]{2}{*}{$\begin{array}{l}\text { Elabo- } \\
\text { ration }\end{array}$} & \multicolumn{3}{|c|}{ Release 1} & \multicolumn{3}{|c|}{ Release K } & \multirow{2}{*}{$\begin{array}{c}\text { Closing } \\
\text { a } \\
\text { project }\end{array}$} \\
\hline & & & $\begin{array}{c}\text { Increment } \\
1.1\end{array}$ & $\begin{array}{c}\text { Increment } \\
1.2\end{array}$ & $\begin{array}{c}\text { Transition } \\
1\end{array}$ & $\begin{array}{c}\text { Increment } \\
\text { K.1 }\end{array}$ & $\begin{array}{c}\text { Increment } \\
\text { K. } 2\end{array}$ & $\begin{array}{c}\text { Transition } \\
\text { K }\end{array}$ & \\
\hline
\end{tabular}

Figure 3. XPrince project lifecycle. Source: Nawrocki et al. (2006).

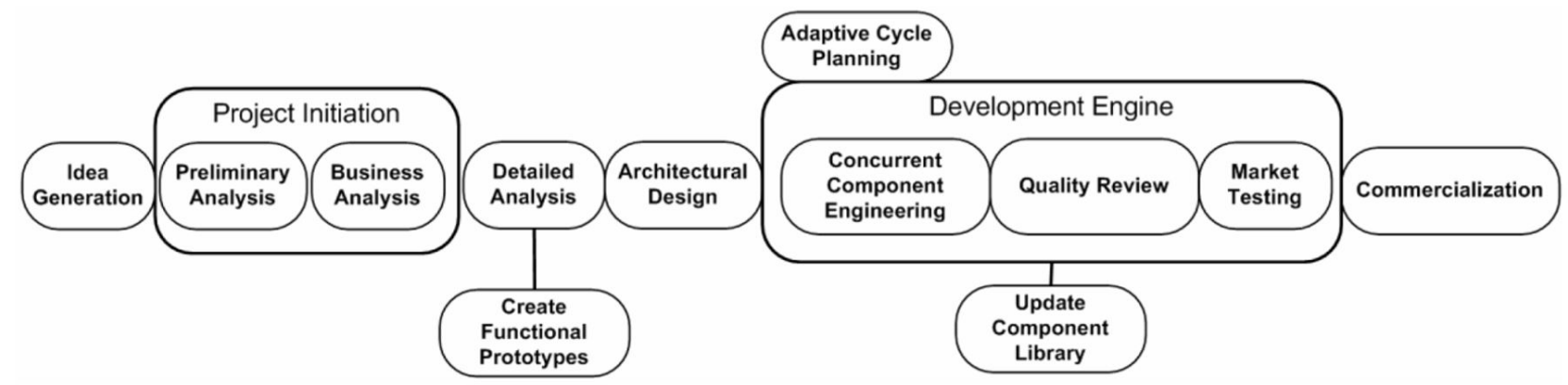

Figure 4. Hybrid Process of Design Methodology. Source: Rahimian and Ramsin (2008). 


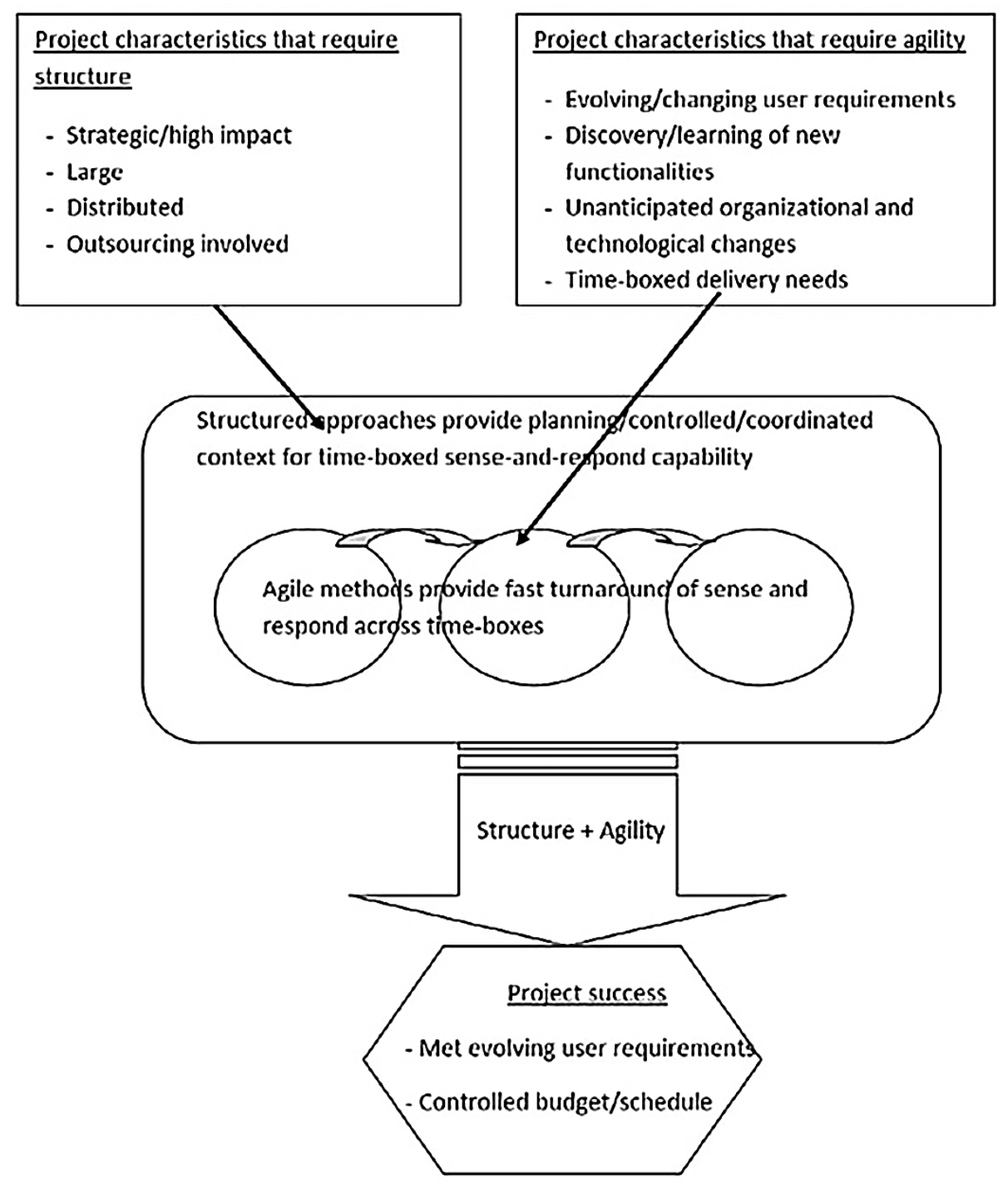

Figure 5. Characteristics of the project that favor a Hybrid approach. RFC's: Request For Changes. Source: Batra et al. (2010).

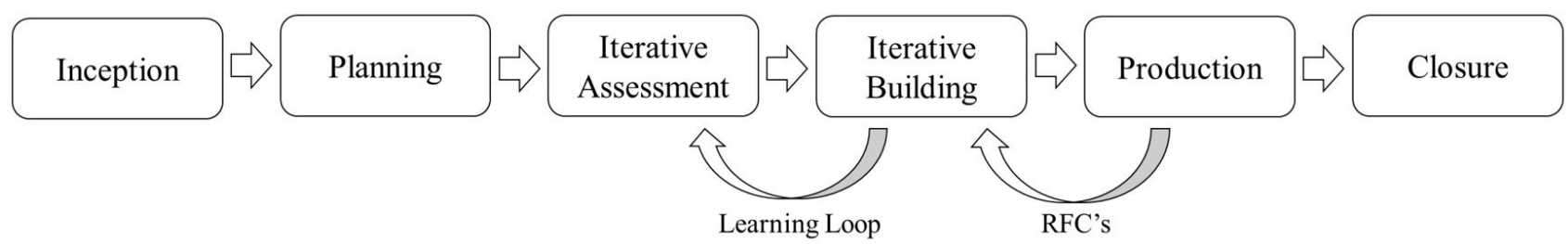

Figure 6. Agile Model of the Disciplined Hybrid process. RFC's: Request For Changes. Source: Zaki and Moawad (2010).

decisions. The traditional practices indicate to solve this issue are to use video conferencing, phone calls, or even develop tools for the client to add new features. From this investigation point of view, traditional practices come from bodies of knowledge and are, for example, the development of the Gantt chart and the WBS (Work Breakdown Structure). The practices cited by the authors are adopted in different project management approaches. Furthermore, the solutions' effectiveness is not explored.
In this way, the model is considered an agile model with the missing information indicating how to combine the project management approaches.

\subsection{Agile reference model for large projects}

The model is an adaptation of the IPVM2 method (CONFORTO; AMARAL, 2010) for managing complex product projects, for example, large equipment and cars (AMARAL et al., 2011, p. 52). Figure 7 presents the model. 


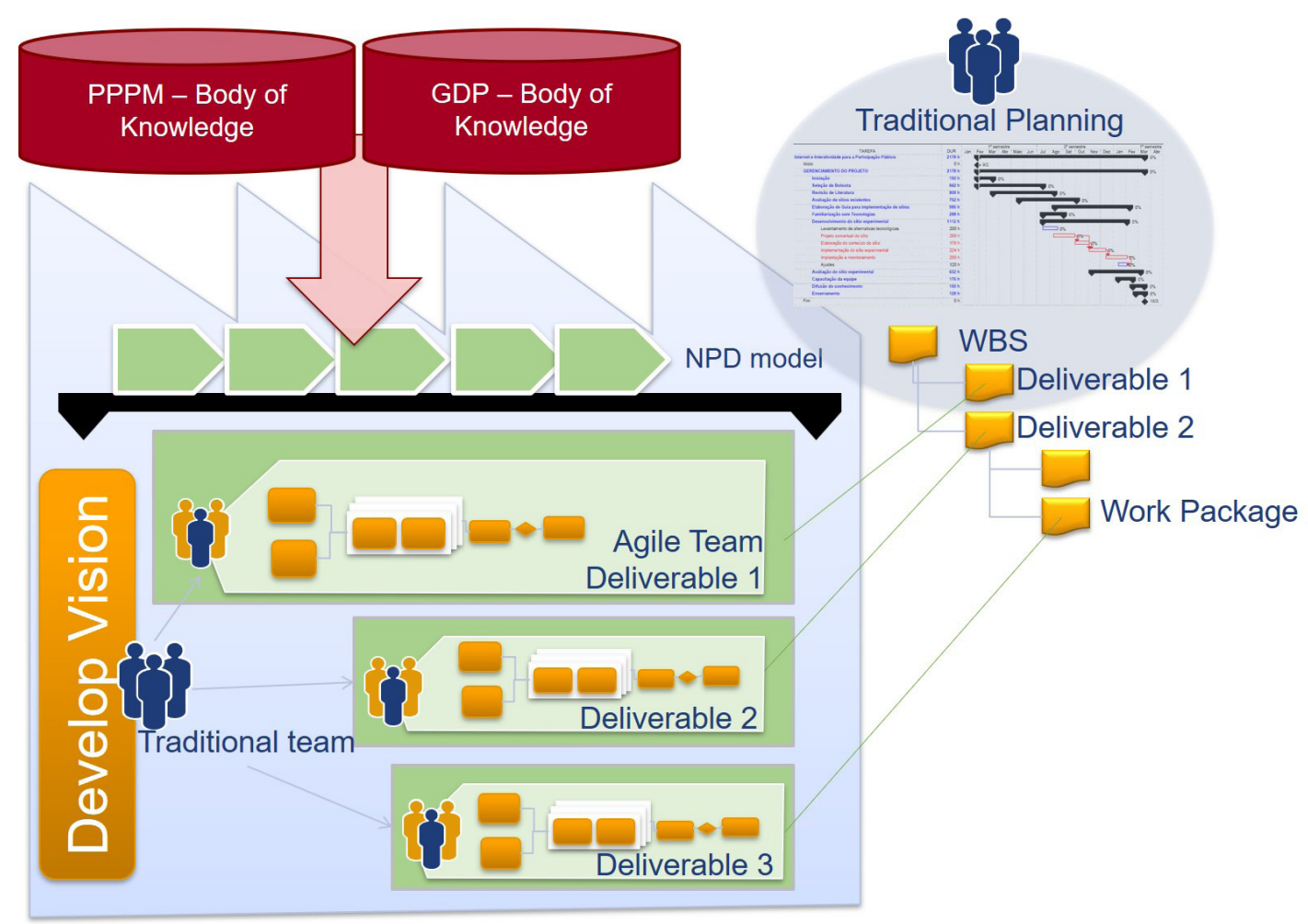

Figure 7. Using the reference model for large projects (AMARAL et al., 2011, p. 52), translated by the author. PPPM: Portfolio, Program, and Project Management; GDP: Product Develpment Management.

The authors suggest the combined use of agile management with a product development reference model and a traditional planning process. They recommend developing the product vision and proposed traditional scheduling tools, such as WBS, in order to prepare the complete plan consisting of the final product and the major deliveries, taking into account the highest possible degree of independence and well-defined interfaces. Furthermore, members of the management team should be allocated to the coordination of agile operations teams responsible for specific deliveries.

The practices identified at this proposal are activity definition and Problem/opportunity declaration classified as both, the traditional technique WBS decomposition, and the tool white board classified as both. This research does not identify any agile practices.

The authors should include more information or specific recommendations about how integrate agile and traditional practices and project teams. The principal contribution is the indication of NPD process with agile iteration development.

\subsubsection{Tragile}

Tragile is a framework used to represent the combination of traditional guidelines and practices with agile principles and practices (SEYAM; GALAL-EDEEN, 2011) as illustrated in Figure 8.
The Tragile predominantly adopts agile practices such as requirements prioritization action, product backlog, User stories, Daily Scrum meeting, Product Architecture, and Retrospective Review techniques. Other practices classified as both are time and effort estimation, activity decomposition and white board. As a conclusion, we understand the Tragile as an agile model and it does not indicate a way of combining project management practices. However, we identify some differentials between Tragile and APM, which are the use of personas to identify stakeholders, system requirement-based architecture, and documentation of important artifacts.

\subsection{Disciplined Agile Delivery (DAD)}

Disciplined Agile Delivery (DAD) represents a method that combines elements of agile methods, such as XP, Scrum, and Lean Software Development, with a development life cycle (AMBLER, 2013). Figure 9 illustrates the method.

The agile practices identified are Sprint Backlog, Product Backlog, Product Architecture, Daily Scrum Meeting techniques. The practices classified as both are project scope definition and activity decomposition technique.

Although we found essentially agile practices, four differences between Disciplined Agile Delivery (DAD) and APM should be are highlighted. The first is the definition of the development life cycle with phases and clear objectives. The second is the similarity between the 


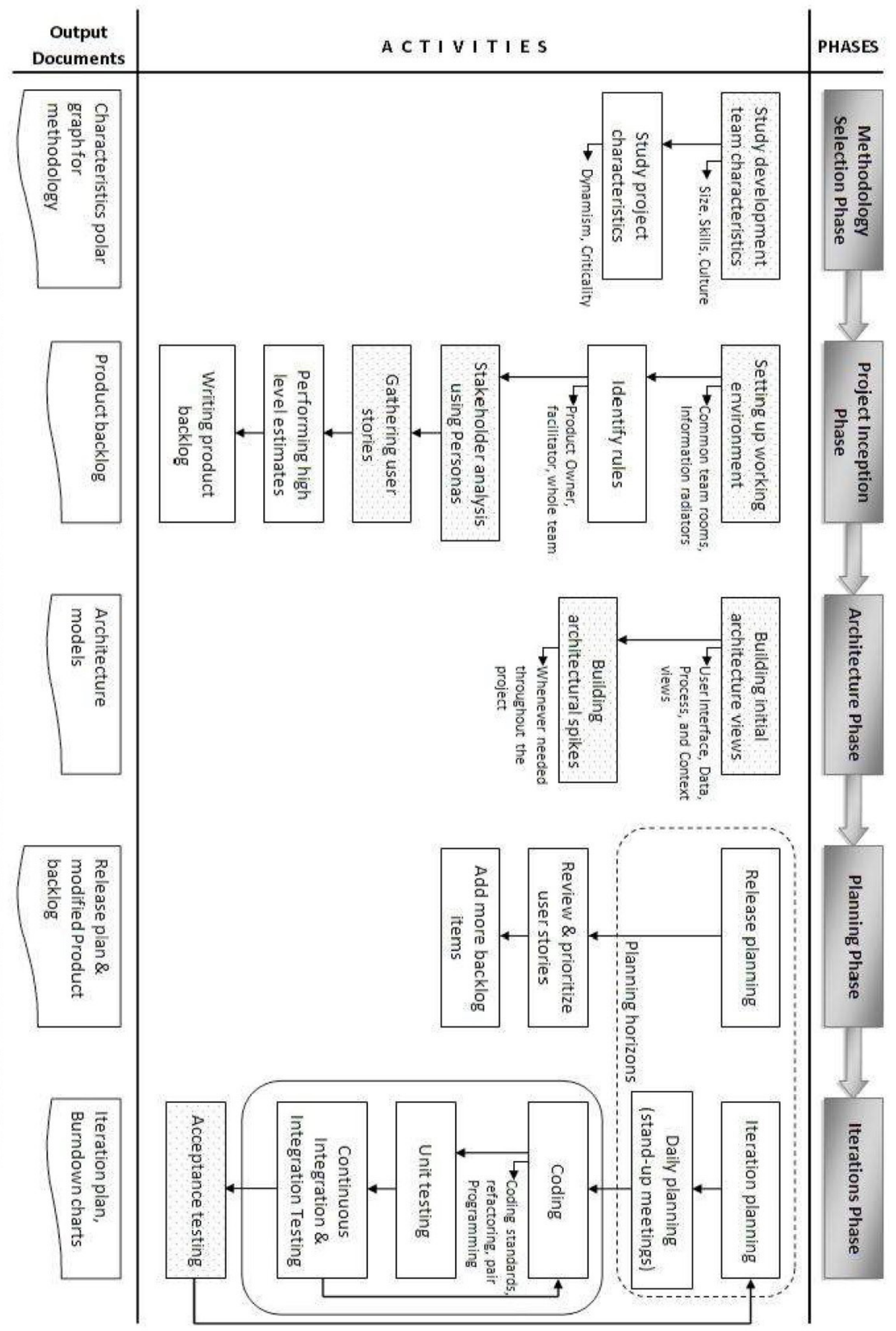

Figure 8. Proposed diagram for the Tragile framework. Source: Seyam and Galal-Edeen (2011). 


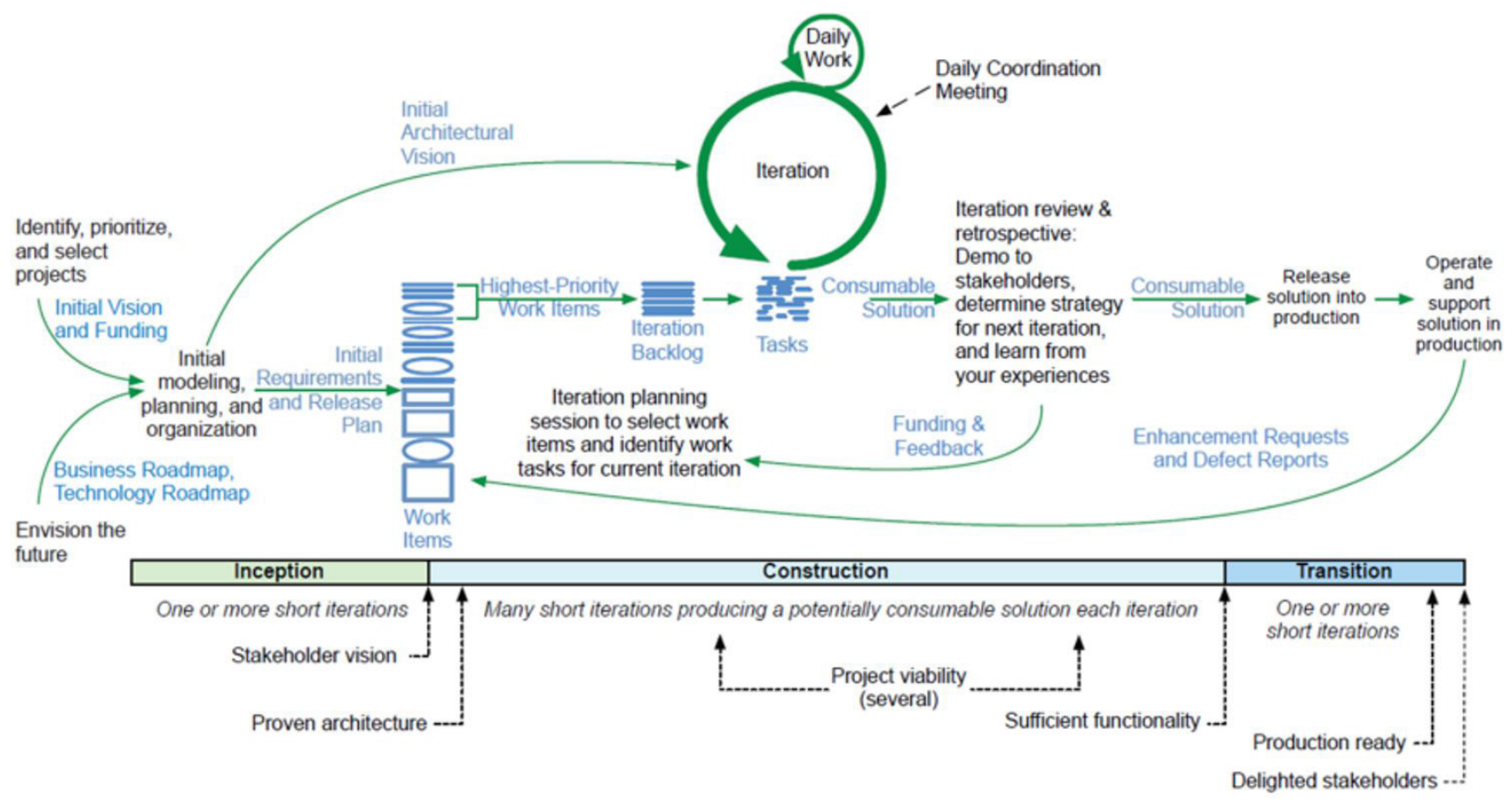

Figure 9. Disciplined Agile Delivery lifecycle. Source: Ambler (2013).

inception stage and the up-front stage of development. Both differences aim to initiate the project, establish the project team and a shared vision identify project risks, and explore the initial scope. The third difference is considering the documentation to be a part of project delivery, for example, all the necessary documentation to satisfy a regulatory law. The fourth difference is the formalization of the project's governance through establishing responsibilities, authority, communication, and support for the company's strategy. While some of these differences are similar to traditional practices, like inception phase and documentation, we understand the method could be considered as an agile method.

\subsection{Cocktail model for project management}

The cocktail model is the result of a correlation among the five process groups - Initiation, Planning, Implementation, Control, and Closing, from ISO 21500 for project management and the principles of the Agile Manifesto (BINDER; AILLAUD; SCHILLI, 2014). Figure 10 presents the model.

The model combines traditional management, based on the Waterfall software development model, and Agile iteration development. Two key points are highlighted in the proposal.

The first point occurs in the initiation and high-level planning stage. The initial plan is developed through traditional techniques such as scope definition, creation

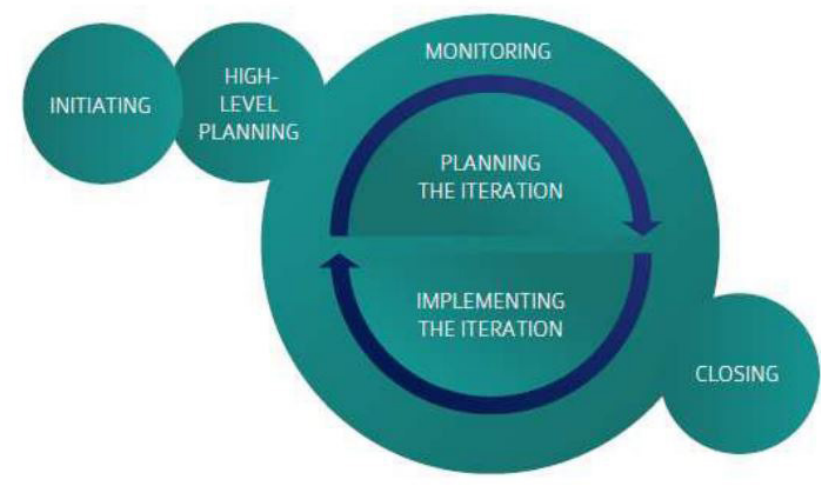

Figure 10. The cocktail model for project management. Source: Binder, Aillaud and Schilli (2014).

of the WBS, estimation of resources and costs, activity sequencing, and schedule. The difference to PMBoK and ISO consists in elaborating an initial plan with a high level of detail rather than detailing the plan in the early stages of the project, considering, for example, for the project schedule: the main milestones, key features, and high-level scope. The definition of project activities also occurs at a high level.

The second point occurs in the planning the iteration and implementing the iteration stages, where iterative development and partial deliveries of the product are recommended. The activities are prioritized and detailed during the iterations in a similar way to the agile practices. 
However, the project plan is updated in each iteration and consistency is maintained with the project's progress.

Thus, we could classify the practices adopted in the cocktail model traditional. The practices identified are sequence activities, develop schedule, and WBS decomposition technique. The practices classified as both are project scope definition and estimate activity resources. We do not identify agile practices.

Binder, Aillaud and Schilli (2014) indicate some recommendations to combine agile and traditional practices, however, but none agile practices are identified. Furthermore, they do not show a systematic way to implement those recommendations. For example, they not discuss how integrate the high level schedule with activities developed during the iteration.

\subsection{Scrumming within the V-model}

Anitha, Savio and Mani (2013) investigated how managing requirements volatility in five different projects at Siemens. The result is a process that combines the V-Model and Scrum for the development phase. Figure 11 presents the model.
The work main contribution is on Requirement Management. Anitha, Savio and Mani (2013) address technical and non-technical factors that lead to requirements changes and the strategies to mitigate them. In this way, the authors do not discuss the combination of V-Model and Scrum. Their work mention one project management practice. They recommend the agile practice of themes, epics and user stories to collect and identify the system requirements in different levels of details.

\subsection{Agile-Stage-Gate}

Cooper (2014) developed a new version of Stage-Gate model using agility principles. According the author the business environment changed significativly in last decades. The demand for new products is faster than never see in past years and this is the motivation for the new proposition. The model maintain the idea of phases and gates. The distinction is the customer participation during all development, at the gates, and the introduction of iterative practices inside each phase as described for Sommer et al. (2015). In Cooper (2016) and Cooper (2017) is possible identify more details about the Agile-Stage-Gate model.

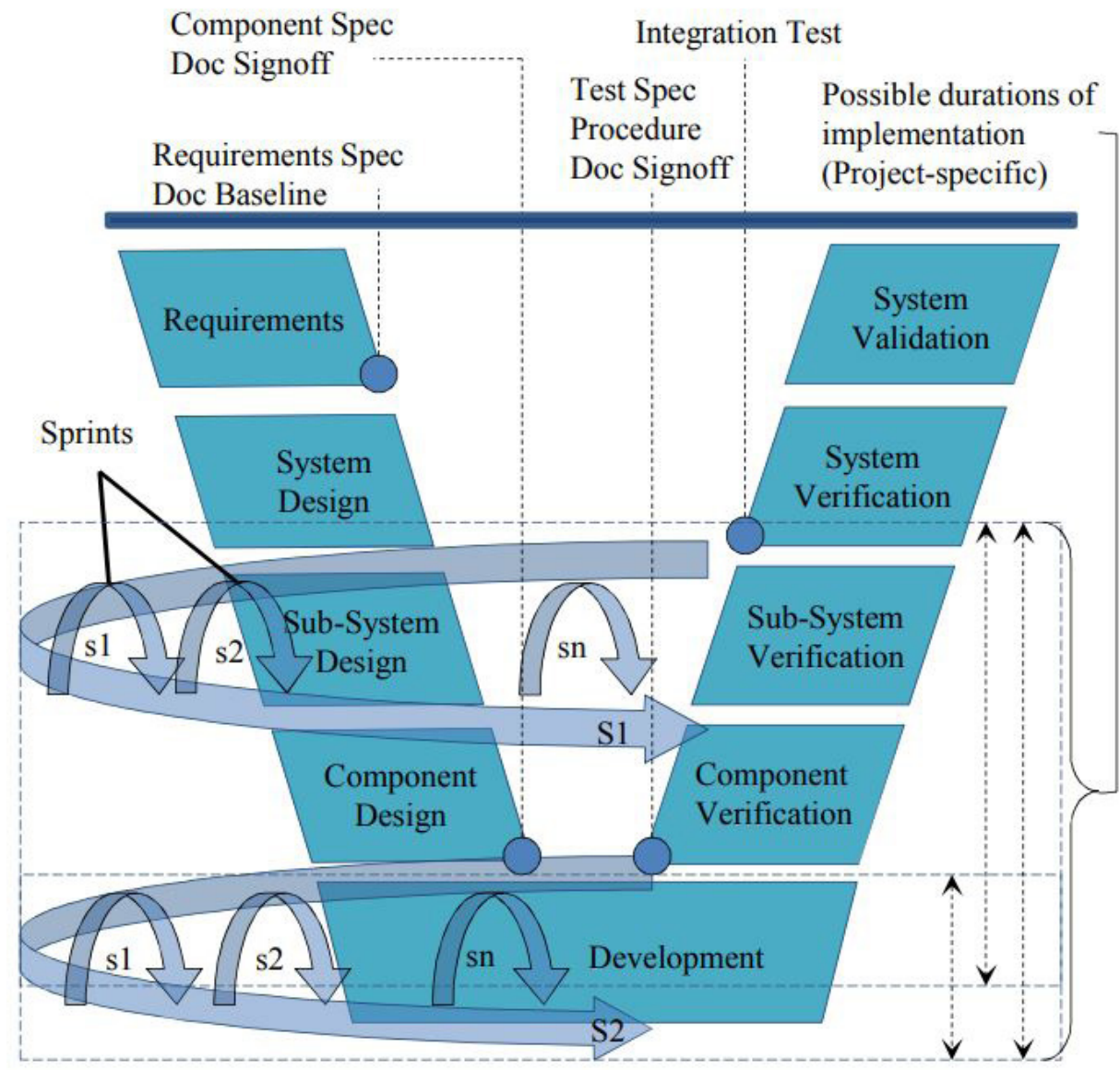

Figure 11. Scrumming within the V-Model. S: Sprint (Sprint 1; Sprint 2...). Source: Anitha, Savio and Mani (2013). 


\subsection{Scrum framework for new product development}

The framework is a result of an investigation about Scrum implementation in five industrial companies (SOMMER et al., 2015). The framework is presented in Figure 12 and it combines the structure provided by a Stage-Gate model and project execution through Scrum method.

The framework presents two key points that should be highlighted. The first is the three planning levels. The first level is the strategic project management for product portfolio management and steering committee. Value-Chain/project portfolio coordination is the tactical planning level focus on resource planning and knowledge sharing across the project teams. The level should be managed using a physical board to coordinate resources among the project teams. At last, the third level is the project execution using Scrum method.

The second key point is the Feasibility study. It is a process that objectives refine the project vision and develop the initial product backlog and prototype. The Scrum team leads the process with main stakeholders departments and all participants improve their understanding about the product.

The agile practices identified are Product Backlog and Sprint Backlog technique. The practices classified as both are estimate activity resources, and meetings, white board, and prototype tools. None traditional practices are identified in this model. We understand the Scrum framework indicates a combination of NPD process and agile iteration development. Nevertheless, it need be detail to discuss the combination of traditional and agile practices.

The Table 4 presents the frequency of all cited practices identified. As a conclusion about the practices being adopts
Table 4. Frequency of cited project management practices.

\begin{tabular}{|c|c|}
\hline Project Management Practices & Frequency \\
\hline \multicolumn{2}{|l|}{ Agile } \\
\hline \multicolumn{2}{|l|}{ Action } \\
\hline Requirements Prioritization & 5 \\
\hline Control Scope Changes & 2 \\
\hline \multicolumn{2}{|l|}{ Technique } \\
\hline Product Architecture & 5 \\
\hline Product Backlog & 6 \\
\hline Daily Scrum Meeting & 4 \\
\hline Sprint Backlog & 2 \\
\hline User stories & 2 \\
\hline Retrospective Review & 2 \\
\hline \multicolumn{2}{|l|}{ Traditional } \\
\hline \multicolumn{2}{|l|}{ Action } \\
\hline Sequence Activities & 1 \\
\hline Develop Schedule & 1 \\
\hline \multicolumn{2}{|l|}{ Technique } \\
\hline Business Case & 2 \\
\hline \multicolumn{2}{|l|}{ Both } \\
\hline \multicolumn{2}{|l|}{ Action } \\
\hline Estimate activity resources & 2 \\
\hline Estimate activity duration & 2 \\
\hline State problem/ opportunity & 2 \\
\hline Define project Scope & 3 \\
\hline Identify project work & 1 \\
\hline Activities definition & 1 \\
\hline \multicolumn{2}{|l|}{ Tool } \\
\hline White Board & 3 \\
\hline Prototypes & 1 \\
\hline \multicolumn{2}{|l|}{ Technique } \\
\hline Decomposition & 4 \\
\hline Meeting & 2 \\
\hline Total & 48 \\
\hline
\end{tabular}

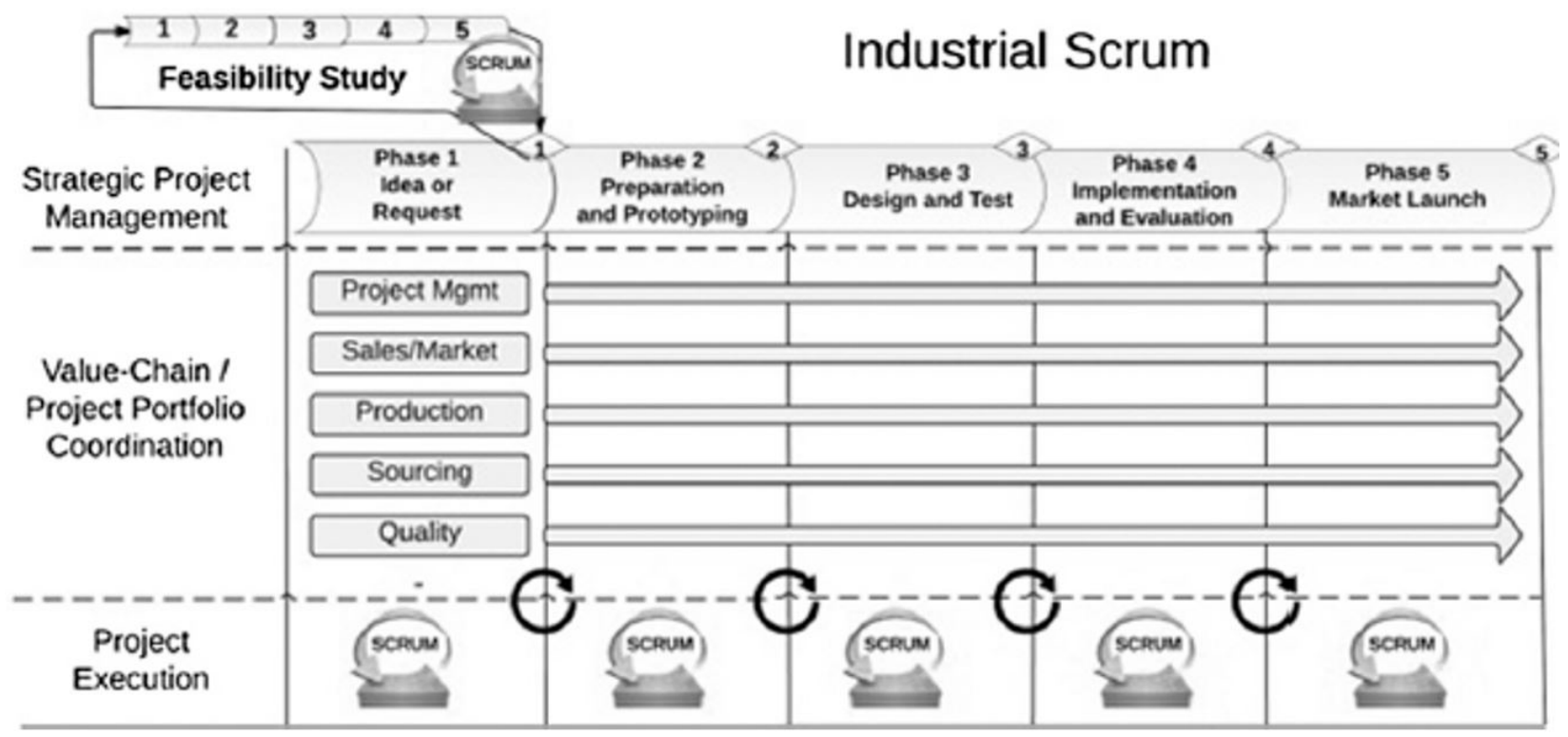

Figure 12. Industrial Scrum framework for new product development. Source: Sommer et al. (2015). 
in the proposals, most of authors adopts essentially agile practices in their proposals. Therefore, the future proposals should indicate more traditional practices for indicate the combination. Another problem is the practices integration, which none of the proposal presents a systematic way to integrate them.

\section{Analysis of the combined or hybrid proposals}

In this section we present the analysis of the proposal using the six characteristics of Eder et al. (2014) as evaluation criteria. Our objective is distinguish the combination proposals from APM and TPM. The section presents an analysis of each proposal described herewith, comparing the characteristics as a way to find the gaps and research opportunities.

We understand the Risk Approach as a diagnostic method aimed at identifying the risks associated with the project development environment and a tool that assists in combining. The Risk Approach does not provide details on how to combine project management approaches.

XPrince has three characteristics, two classified as traditional and one as agile. The project plan should indicate all the releases and key features, provide a broad perspective of the project, and the person responsible for preparing the plan is the project manager. Thus, the plan and the planning horizon are classified as traditional. In the Release stage, tests are performed and there is an acceptance evaluation by the project manager, similar to XP. Based on this, the guarantee of the scope achievement is seen as agile. Details on defining the scope, defining the project activities, and how to control the project time are not identified.

The Hybrid process of design methodology does not provide any information on the six characteristics, making it unfeasible to conclude the nature of the approach used. Only a prioritization of requirements and the product's architecture are identified, both classified as agile, according to Eder et al. (2014). No further details of activities, techniques, or tools are given that would assist this investigation.

The Hybrid framework presents information about three characteristics, which were marked as agile. The case study considered a limited horizon for planning the project activities. The control strategy employed was the daily meeting, as prescribed by Scrum. The strategy for achieving the scope was the client's evaluation and feedback. The practices that were identified, according to Eder et al. (2014), were the Product Backlog technique, the action of prioritizing requirements, both classified as agile, and the traditional meeting technique, called a Steering committee. Thus, the framework resembles APM. Details are lacking to affirm whether or not there is a combination of approaches, such as the development of project plans and upgrading through incremental deliveries.
The disciplined hybrid process model has all six characteristics classified as agile. Further classification took place in an attempt to identify the authors' proposal for combining. The action of prioritizing requirements is identified, as well as techniques pertaining to user stories, product backlog, daily meeting, high-level product architecture, and retrospective meeting are classified as agile. The action of declaring a problem or opportunity and estimating its duration and effort are classified in both the approaches. It is regarded as an agile model because of all the characteristics presented.

The agile reference model for large projects has all the characteristics. The authors suggest developing a single project plan based on the traditional model. The action of defining the scope is performed through the product vision, similar to the agile model. Activities are defined using the standard reference model based on the Product Development Process and WBS, classified as traditional. The last three criteria are classified as agile. The planning is performed iteratively by detailing the activities in the short time horizon, time control is obtained by means of short, frequent meetings, and verification is performed using progress feedback and the client's evaluation.

Despite presenting two traditional criteria, it is not possible to infer the combination of approaches. The authors suggest adapting the model in order to apply agile practices in complex environments, but there is a lack of description of how to combine them. Even so, defining packages of activities, such as a traditional action, declaring a problem or opportunity, and the breakdown of activities, are classified as being present in both the approaches.

Tragile has all six characteristics classified as agile. The action of prioritizing requirements and techniques pertaining to user stories, product backlog, daily meeting, and high-level architecture are related to APM. There are subtle differences between Tragile and APM, enhanced with the classification by Eder et al. (2014). Incorporating a high-level architecture, documenting important artifacts, and suggesting the use of different durations for the iterations are differential elements of this method, which are apparently insufficient for treating it as something other than an agile method.

Disciplined Agile Delivery presented all six characteristics classified as agile. Other elements that differ from the method of APM involve the incorporation of a project lifecycle, documentation, and formalization of project governance. Despite these elements, there is no indication that project management practices have been combined.

The Cocktail model has five characteristics: two agile and three traditional, indicating a combination. The Plan, Scope, and Activities are defined using traditional techniques such as scope definition, WBS creation, estimation of resources 
Table 5. Synthesis of the analysis of the combination proposals.

\begin{tabular}{|c|c|c|c|c|c|c|}
\hline & \multirow[b]{2}{*}{ Planning levels } & \multicolumn{5}{|c|}{ Six characteristics (EDER et al., 2014) } \\
\hline & & Scope & Task Definition & $\begin{array}{l}\text { Timespan } \\
\text { for ultimate } \\
\text { task }\end{array}$ & Control & $\begin{array}{l}\text { Quality } \\
\text { Assurance }\end{array}$ \\
\hline $\begin{array}{l}\text { Risk Approach } \\
\text { (BOEHM; TURNER, 2003) }\end{array}$ & & & & & & \\
\hline $\begin{array}{l}\text { XPrince } \\
\text { (NAWROCKI et al., 2006) }\end{array}$ & $\mathrm{T}^{*}$ & & & $\mathrm{~T}$ & & $\mathrm{~A}^{* *}$ \\
\hline $\begin{array}{l}\text { Hybrid Methodology Design } \\
\text { process (RAHIMIAN; RAMSIN, } \\
\text { 2008) }\end{array}$ & & & & & & \\
\hline $\begin{array}{l}\text { Hybrid Framework } \\
\text { (BATRA et al., 2010) }\end{array}$ & A & A & A & & & \\
\hline $\begin{array}{l}\text { Hybrid Disciplined Agile Software } \\
\text { Process Model (ZAKI; MOAWAD, } \\
\text { 2010) }\end{array}$ & A & A & A & A & A & A \\
\hline $\begin{array}{l}\text { Reference model of agile } \\
\text { management for large projects } \\
\text { (AMARAL et al., 2011) }\end{array}$ & $\mathrm{T}$ & A & $\mathrm{T}$ & A & A & A \\
\hline $\begin{array}{l}\text { Tragile (SEYAM; GALAL- } \\
\text { EDEEN, 2011) }\end{array}$ & A & A & A & A & A & A \\
\hline $\begin{array}{l}\text { Disciplined Agile Delivery } \\
\text { (AMBLER, 2013) }\end{array}$ & A & A & A & A & A & A \\
\hline $\begin{array}{l}\text { Cocktail model for project } \\
\text { management } \\
\text { (BINDER; AILLAUD; SCHILLI, } \\
\text { 2014) }\end{array}$ & $\mathrm{T}$ & $\mathrm{T}$ & $\mathrm{T}$ & & A & A \\
\hline $\begin{array}{l}\text { Agile/Stage-Gate hybrid model } \\
\text { (SOMMER et al., 2015) }\end{array}$ & $\mathrm{T} / \mathrm{A}$ & A & A & & & \\
\hline $\begin{array}{l}\text { Scrumming within the V-Model } \\
\text { (ANITHA; SAVIO; MANI, 2013) }\end{array}$ & & & & & & \\
\hline
\end{tabular}

*Tradicional; **Agile.

and costs, activity sequencing, and schedule creation. The model recommends that key stakeholders must approve changes in scope, the prioritization of activities during the iteration. Both recommendations occur in a manner similar to the APM. Thus, the Time and Guarantee are agile. Details regarding the Horizon is not identified.

Scrumming within the V-Model shows no characteristics. The authors focus is on Requirement Management and do not discuss about the model. In this way, it is not possible to identify any of the six characteristics.

Scrum framework for new product development presents three characteristics. The planning levels presents the combination of traditional planning process, with the gates and resource planning, and Scrum sprint planning. Thus, the Plan could be classified as a mix of traditional and agile planning process. During the Feasibility study, project scope is described using Product Vision and the Product Backlog is developed with the initial list of project activities. In this way, the scope and activities are classified as agile. However, this framework does not present how to prioritize the Product Backlog nether how to involve the customer in this process. The framework shows no information about the Horizon, Time and Guarantee.

Table 5 presents a synthesis of the analysis relating the ten combination proposals and six characteristics from Eder et al. (2014).

\section{Conclusions}

The proposals by Boehm and Turner (2003), Nawrocki et al. (2006), Rahimian and Ramsin (2008), and Anitha, Savio and Mani (2013) describe few characteristics that makes unviable to infer how to combine project management approaches. The Zaki and Moawad (2010), Seyam and Galal-Edeen (2011), and Ambler (2013) group differ little from the perspective of APM, and the main differences of these proposals involve the incorporation of a development process and the documentation of important artifacts. Amaral et al. (2011), Binder, Aillaud and Schilli (2014), and Sommer et al. (2015) provide a more specific recommendation, where the traditional project plan and agile iterative planning are used, although the proposals do not present details on how to combine them. Thus, in general, the proposals are considered to be in a conceptual phase. 
All proposals did not include a systematic procedure indicating how to combine the practices and principles of both the approaches. The authors did not establish steps, or order guidelines to combine. Furthermore, references describing the application were not found. Thus, the literature presents a gap in relation to procedures that combine the agile and traditional practices.

The gap prevents progress on the subject. Which principles, practices, and tools should be considered in order to develop combined project management processes? In addition, there is the issue of using this combination outside the context of information systems or software development, to which most of the cited authors belong.

The research also leads to the conclusion that there may be two strategies for planning the combined project, identified in eight combination proposals. The bottom-up strategy consists of combining APM and a development process that includes defined phases and the main deliveries according to Zaki and Moawad (2010), Seyam and Galal-Edeen (2011), Ambler (2013), and Sommer et al. (2015). The top-down strategy considers the development of a traditional project plan and implementation through iterations or sprints, as presented in Nawrocki et al. (2006), Batra et al. (2010), Amaral et al. (2011), and Binder, Aillaud and Schilli (2014).

It can also be concluded that the main characteristic of the combination, observed in this top-down strategy, is the concomitant presence of a traditional project plan, based on a schedule, with the simplified plans proposed in the APM approach: Product Backlog and Spring Backlog. The challenge is to coordinate the content of these plans and deal with them together.

Future research and further discussion should include the development of procedures in accordance with each combination strategy. These procedures should indicate how to coordinate different planning levels in accordance with the first Eder's characteristic. Another future research is comparing these two strategies with Agile and Traditional project management.

\section{References}

AMARAL, D. C. et al. Gerenciamento ágil de projetos: aplicação em produtos inovadores. São Paulo: Saraiva, 2011.

AMBLER, S. W. Going beyond Scrum: disciplined agile delivery. Disciplined Agile Consortium, 2013. p. 1-16. (Disciplined Agile Consortium, White Paper Series).

ANITHA, P. C.; SAVIO, D.; MANI, V. S. Managing requirements volatility while "Scrumming" within the V-Model. In: INTERNATIONAL WORKSHOP ON EMPIRICAL REQUIREMENTS ENGINEERING
(EMPIRE), 3., 2013, Rio de Janeiro. Proceedings... New York: IEEE, 2013. p. 17-23.

BARLOW, J. B. et al. Overview and guidance on agile development in large organizations. Communications of the Association for Information Systems, v. 29, n. 2, p. 25-44, 2011.

BATRA, D. et al. Balancing agile and structured development approaches to successfully manage large distributed software projects: a case study from the cruise line industry. Communications of the Association for Information Systems, v. 27, n. 21, p. 379-394, 2010. http://dx.doi. org/10.17705/1CAIS.02721.

BINDER, J.; AILLAUD, L.; SCHILLI, L. The project management cocktail model: an approach for balancing agile and ISO 21500. $\mathbf{2 7}^{\text {th }}$ IPMA World Congress. Procedia: Social and Behavioral Sciences, v. 119, p. 182191, 2014. http://dx.doi.org/10.1016/j.sbspro.2014.03.022.

BOEHM, B. Get ready for agile methods, with care. IEEE Computer Society, v. 35, n. 1, p. 64-69, 2002. http://dx.doi. org/10.1109/2.976920.

BOEHM, B.; TURNER, R. Using risk to balance agile and plan-driven methods. Computer, v. 36, n. 6, p. 57-66, 2003. http://dx.doi.org/10.1109/MC.2003.1204376.

BOEHM, B.; TURNER, R. Balancing agility and discipline: a guide for the perplex. Boston: Pearson Education, 2004.

BOEHM, B.; TURNER, R. Management challenges to implementing agile processes in traditional development organizations. IEEE Computer Society, v. 22, n. 5, p. 3039, 2005. http://dx.doi.org/10.1109/MS.2005.129.

CONFORTO, E. C.; AMARAL, D. C. Evaluating an agile method for planning and controlling innovative projects. Project Management Journal, v. 41, n. 2, p. 73-80, 2010. http://dx.doi.org/10.1002/pmj.20089.

CONFORTO, E. C.; AMARAL, D. C.; SILVA, S. L. Roteiro para revisão bibliográfica sistemática: aplicação no desenvolvimento de produtos e gerenciamento de projetos. In: CONGRESSO BRASILEIRO DE GESTÃO DE DESENVOLVIMENTO DE PRODUTOS, 8., 2011, Porto Alegre. Anais... Porto Alegre: UFRGS, 2011. Available from: <http://www.ufrgs.br/cbgdp2011/downloads/9149. pdf>. Access in: 29 July 2019.

CONFORTO, E. C.; REBENTISCH, E.; AMARAL, D. C. Project management agility global survey. Cambridge: Massachusetts Institute of Technology, Consortium for Engineering Program Excellence, 2014. Available from: $<$ http://www.pmi.org/ /media/PDF/Surveys/PM-AgilityGlobal-Survey-PMI-Executive-Report-v10.ashx>. Access in: 29 July 2019. 
COOPER, R. G. What's next? After stage-gate. Research Technology Management, v. 57, n. 1, p. 20-31, 2014. http:// dx.doi.org/10.5437/08956308X5606963.

COOPER, R. G. Agile-stage-gate hybrids. Research Technology Management, v. 59, n. 1, p. 21-29, 2016. http:// dx.doi.org/10.1080/08956308.2016.1117317.

COOPER, R. G. Idea-to-launch gating systems: better, faster, and more agile idea-to-launch gating systems. Research Technology Management, v. 60, n. 1, p. 48-52, 2017. http:// dx.doi.org/10.1080/08956308.2017.1255057.

EDER, S. et al. Differentiating traditional and agile project management approaches. Production, v. 25, n. 3, p. 482-497, 2014. http://dx.doi.org/10.1590/S010365132014005000021 .

FERNANDEZ, D.; FERNANDEZ, J. Agile project management: agilism versus tradicional approaches. Journal of Computer Information Systems, v. 49, n. 2, p. 10, 2008.

GALAL-EDEEN, G. H.; RIAD, A. M.; SEYAM, M. S. Agility versus discipline: is reconciliation possible? In: INTERNATIONAL CONFERENCE ON COMPUTER ENGINEERING \& SYSTEMS (ICCES), 2007, Cairo, Egypt. Proceedings... New York: IEEE, 2007. p. 331-337.

MAGDALENO, A. M.; WERNER, C. M. L.; ARAUJO, R. M. Reconciling software development models: a quasisystematic review. Journal of Systems and Software, v. 85 , n. 2, p. 351-369, 2012. http://dx.doi.org/10.1016/j. jss.2011.08.028.

NAWROCKI, J. et al. Balancing agility and discipline with XPrince. In: INTERNATIONAL WORKSHOP ON RAPID INTEGRATION OF SOFTWARE ENGINEERING TECHNIQUES, 2006, Geneva, Switzerland. Proceedings... Berlin: Springer, 2006. v. 3943, p. 266-277.

PROJECT MANAGEMENT INSTITUTE - PMI. PMI'S pulse of the profession. driving success in challenging times. Newtown Square, 2012. Available from: <http:// www.pmi.org/ /media/PDF/Research/2012_Pulse_of_the_ profession.ashx $>$. Access in: 29 July 2019.

RAHIMIAN, V.; RAMSIN, R. Designing an agile methodology for mobile software development: a hybrid method engineering approach. In: INTERNATIONAL CONFERENCE ON RESEARCH CHALLENGES IN INFORMATION SCIENCE (RCIS), 2., 2008, Marrakech. Proceedings... New York: IEEE, 2008. p. 337-342. http:// dx.doi.org/10.1109/RCIS.2008.4632123.

SERRADOR, P.; PINTO, J. K. Does agile work? A quantitative analysis of agile project success. International Journal of Project Management, v. 33, n. 5, p. 1040-1051, 2015. http://dx.doi.org/10.1016/j.ijproman.2015.01.006.

SEYAM, M. S.; GALAL-EDEEN, G. H. Traditional versus agile: the tragile framework for information systems development. International Journal of Software Engineering, v. 4, n. 1, p. 63-93, 2011.

SHENHAR, A.; DVIR, D. Project management research: the challenge and opportunity. Project Management Journal, v. 38, n. 2, p. 93-99, 2007. http://dx.doi. org/10.1177/875697280703800210.

SOMMER, A. F. et al. Improved product development performance through agile/stage-gate hybrids: the nextgeneration stage-gate process? Research Technology Management, v. 58, n. 1, p. 34-45, 2015.

VINEKAR, V.; SLINKMAN, C. W.; NERUR, S. Can agile and traditional systems development approaches coexist? An ambidextrous view. Information Systems Management, v. 23, n. 3, p. 31-42, 2006. http://dx.doi.org/10.1201/1078. 10580530/46108.23.3.20060601/93705.4.

WYSOCKI, R. K. (2007). Effective project management. 4th ed. Indianapolis: John Wiley \& Sons.

ZAKI, K. M.; MOAWAD, R. A hybrid disciplined agile software process model. In: INTERNATIONAL CONFERENCE ON INFORMATICS AND SYSTEMS (INFOS), 7., 2010, Cairo, Egypt. Proceedings... Cairo: Cairo University, 2010. p. 1-8. 
Appendix 1. Project managemet practices list.

\begin{tabular}{|c|c|c|c|}
\hline Action & Source & Technique & Source \\
\hline Adding Detail to User Stories Sooner & Agile & Planning Poker & Agile \\
\hline Ask for a Time Commitment & Agile & Case point estimates & Agile \\
\hline Control Scope Changes & Agile & Estimating stories by comparison & Agile \\
\hline Determine Target Velocity / Estimating Velocity / Velocity & Agile & Experiment & Agile \\
\hline Identify and dimension floats & Agile & Feature cards & Agile \\
\hline Prioritize requirements & Agile & Product Backlog & Agile \\
\hline Prioritize team work & Agile & Customer Focus Groups & Agile \\
\hline Measure the complexity & Agile & Daily Scrum Meeting & Agile \\
\hline Collect Requirements & Traditional & Product Architecture & Agile \\
\hline Control Scope & Traditional & Product Feature List & Agile \\
\hline Develop Project Charter & Traditional & Product Vision Box & Agile \\
\hline Define Activities & Traditional & Project Data Sheet & Agile \\
\hline Develop Schedule & Traditional & Sprint Retrospective Meeting & Agile \\
\hline Finalize Project Plan & Traditional & Sprint Review Meeting & Agile \\
\hline Sequence Activities & Traditional & Sprint Backlog & Agile \\
\hline Verify Scope & Traditional & Forecasting/ Estimating Velocity & Agile \\
\hline Define Product Scope & Traditional & Applying leads and lags & Traditional \\
\hline Control Project Plan & Both & Alternatives Identification & Traditional \\
\hline Identify project work (product, deliverables, etc.) & Both & Product Analysis & Traditional \\
\hline Statement of Problem/ Opportunity & Both & Reserve Analysis & Traditional \\
\hline Define Project Scope & Both & Performance Analysis & Traditional \\
\hline Estimate Activity Durations & Both & Decision Tree & Traditional \\
\hline \multirow[t]{2}{*}{ Estimate Activity Resources } & Both & Business problem definition & Traditional \\
\hline & & Chartering & Traditional \\
\hline Tool & Source & Schedule Compression & Traditional \\
\hline Mockups & Agile & Critical Path Method & Traditional \\
\hline Power point presentation & Both & Delphi Technique & Traditional \\
\hline Meeting minute & Both & Focus Groups & Traditional \\
\hline Cards/ Sticky Notes & Both & Duration and Total Work Effort & Traditional \\
\hline Poster & Both & Earned Value Analysis & Traditional \\
\hline Checklist & Both & Interview Stakeholders & Traditional \\
\hline Drawing / Sketch & Both & Analogous Estimating & Traditional \\
\hline Diagram / Graphical presentation / Chart & Both & Parametric Estimating & Traditional \\
\hline Script/ Roadmap & Both & Bill of Material & Traditional \\
\hline E-mail & Both & Analogous Estimating & Traditional \\
\hline List & Both & Observation & Traditional \\
\hline Mental models / Process Maps & Both & Critical Chain Project Management (CCPM) & Traditional \\
\hline Models / Prototypes / Templates & Both & Event on node diagram & Traditional \\
\hline Worksheet / Table & Both & Model / Template & Traditional \\
\hline White board & Both & Resource Leveling & Traditional \\
\hline Questionnaire & Both & Expert Judgment & Traditional \\
\hline Project Management Software & Both & Program Evaluation and Review Technique & Traditional \\
\hline Database & Traditional & Simulation & Traditional \\
\hline Contract & Traditional & Stoplight Reports & Traditional \\
\hline Quality Manual & Traditional & Three-Point Estimates & Traditional \\
\hline \multirow[t]{9}{*}{ Report } & Traditional & Group Creativity Techniques & Traditional \\
\hline & & Business case & Traditional \\
\hline & & Gantt Chart & Traditional \\
\hline & & Balanced Scorecard & Both \\
\hline & & Rolling wave planning & Both \\
\hline & & Meeting & Both \\
\hline & & Comparing Pairs & Both \\
\hline & & Dot Voting & Both \\
\hline & & Decomposition & Both \\
\hline
\end{tabular}

